\title{
Diagnosis and therapy of copulatory disorders of the stallion
}

\author{
E. Klug, C.P. Bartmann and Heidrun Gehlen \\ Klinik für Pferde der Tierärztlichen Hochschule Hannover, Germany
}

\begin{abstract}
Summary
Copulatory disorders of the stallion occur in various clinical forms and varying incidence. They are clinically manifest through libido, erectile, ejaculatory and co-ordination disorders in the copulatory reflex chain. The causes are rooted in handling, morphofunction and the endocrine neuromuscular function of the sexual processes of the stallion. In addition to a summary of the causes, diagnostics and therapeutic possibilities for the various disease complexes, description of spongial erectile dysfunction, as a particular clinical manifestation of erectile disorders of the stallion, and their treatment, are discussed.
\end{abstract}

Keywords: $\quad$ stallion, sexual behaviour, copulatory disorders, , erectile and ejaculatory dysfunction

\begin{abstract}
Diagnose und Therapie von Kopulationsstörungen des Hengstes
Kopulationsstörungen beim Hengst kommen in verschiedenen Erscheinungsformen und unterschiedlicher Inzidenz vor. Sie manifestieren sich klinisch im wesentlichen in Libido-, Erektions-, Ejakulations- und Kordinationstörungen der Kopulationsreflexkette. Die Ursachen liegen im Bereich der Handhabung, der Morphofunktion und der endokrin-neuromuskulären Funktion der Sexualabläufe des Hengstes. Neben einer Übersicht der Ursachen, Diagnostik und möglicher Therapien der einzelnen Krankheitskomplexe wird die spongial-erektile Dysfunktion als eine besondere klinische Manifestation der Erektionsstörung beim Hengst und deren Behandlung beschrieben.
\end{abstract}

Schlüsselwörter: Hengst, Sexualverhalten, Kopulationsstörungen, erektile und ejakulatorische Fehlfunktionen

\section{Introduction}

Disturbances in the mating behaviour of the stallion are generally associated with libido sexualis, erection, ejaculation and a correct sequence of the mating reflexes. For this reason a stallion's inability to cover - impotentia coeundi - may have various clinical manifestations. There are four forms to differentiate between; lack of libido sexualis, disorders in erection or ejaculation and lack of coordination during the mating process. Whilst the findings in the case of a lack of libido show a relatively uniform picture, there is significant variation in the symptomatics associated with erectile and ejaculatory dysfunction and both may, to a certain extent, overlap. It is therefore of particular importance to identify the possible location of the copulatory disorder, in any stallion presented for andrological investigation, as the history can be misleading through its unscientific nature and lack of detail. Not only lay-persons treat mating and fertility disorders uncritically and with a lack of differentiation between the two. The following summary discusses the occurrence, the diagnostics, the therapeutic possibilities and the prognosis in disorders affecting the mating potential of the stallion. Suggestions for therapy not only include those based on personal experience but also cover international literature. Not all of the possible changes can be described in detail, however, those of particular practical-clinical importance are presented in depth. In addition to this it was not possible to consider the extensive complex surrounding the equine sexual behaviour with respect to the etho- and etho-pathologic processes, as presented in the numerous studies of McDonnell (1992).

\section{Disorders of the libido sexualis}

Libido sexualis is the technical term for the sexual appetence required to carry out the mating process. Its presence varies and in extreme cases it may be completely absent. Considerable primary lack of libido is present when, in an andrologically inconspicuous proband, there is no manifestation of sexual drive from the onset of sexual maturity. Such a primary disorder is only rarely seen in the stallion; in general changes in sexual behaviour are secondary. The sexual drive manifests itself through the sensory recognition of the sexual partner, the reflectorial functional activation of the copulatory organs and the initial copulatory intentions. In the stallion these partial complexes correspond to species specific symptoms and processes, which may be individually or collectively recorded, giving quantitatively and therefore objective results. Recordings can be made as to the time required from the presentation of a mare in season until the first movements indicating willingness to mate are seen (reaction time). In the case of stallions with a normal libido this should be in the order of seconds, at the most a few minutes. As early as 1942, Götze, suggested that the guarantee of performance and the guarantee dead-line, for 
sexual breeding acceptability, which accompanies the sale of breeding stallion should include a preparatory period of no longer than 20 minutes. Merkt and Klug (1989) allow the stallion, a reaction time of up to 10 minutes. The reaction time has been implemented in the determination of libido by other research groups, (Pickett et al. 1970), who took seasonal variations, with significantly longer time periods in the late autumn and winter months, into account. However, these studies give no norm or minimum times. Other measurable parameters include time to erection, the time between first mount and ejaculation and the number of mounts required until ejaculation (Berndtson et al. 1974 and 1979; Pickett et al. 1989).

The causes of disturbances in libido are as manifold as the number of complexes which lead to manifestation of a normal and undisturbed libido sexualis. This involves an uptake of specific sensory signals, their processing in the CNS and their transfer to efferent nerves directed at target organs in the genital and other somatic regions. A minimum concentration of circulating gonadal androgen, primarily testosterone, is essential for the production of the chain of reactions. It is however not necessary for its maintenance. Several observations have been made of castrated stallions showing signs of libido and even mating months or even years after castration. An example of their application, is their effective use as teasers (Klug et al. 1976).

Factors, other than a certain individual and seasonal variation, influencing libido sexualis include age, sexual experience management and handling. All may play a stabilizing or destabilizing role (see table 1). There is no obvious correlation between age and libido. At the most uncertainty, which masks or even suppresses the signs of libido, may be observed, to a greater or lesser extent, in young or maiden stallions. Careful handling of these stallions brings them quickly back into a normal sexual rhythm. There are no rules as to any age related reduction in the sexual drive in-

Tab. 1: Disorders of Libido sexualis in the stallion

Störungen der Libido sexualis beim Hengst

\begin{tabular}{|c|c|c|}
\hline $\begin{array}{l}\text { lack of libido } \\
\text { Libidomangel } \\
\text { complete/ } \\
\text { incompl. }\end{array}$ & $\begin{array}{l}\text { incidence } \\
\text { Vorkommen } \\
\text { young/old } \\
\text { stallion }\end{array}$ & $\begin{array}{l}\text { therapeutic measures } \\
\text { therapeutische Maßnahmen }\end{array}$ \\
\hline primary & $(-)$ ? young & \\
\hline $\begin{array}{l}\text { hormone } \\
\text { insufficiency }\end{array}$ & $(+) ?$ young & $\begin{array}{l}\text { tentative short time GNRH } \\
\text { applic.; no sex-steroids! }\end{array}$ \\
\hline secundary & & \\
\hline $\begin{array}{l}\text { negative } \\
\text { experience }\end{array}$ & $+\quad$ young/old & $\begin{array}{l}\text { compensation of causal } \\
\text { trauma }\end{array}$ \\
\hline exhaustion & + young/old & $\begin{array}{l}\text { alterations in individual } \\
\text { mating frequency }\end{array}$ \\
\hline $\begin{array}{l}\text { select. mating } \\
\text { behaviour }\end{array}$ & $+\quad$ young/old & $\begin{array}{l}\text { alterations in stallion hand- } \\
\text { ling is difficult but possible }\end{array}$ \\
\hline malhandling & $+\quad$ young/old & avoid mistakes in handling \\
\hline
\end{tabular}

spite of the fact that elder stallions show a reduced endocrine reagibility (Gusmao 1988). The observation of small increases in the reaction time shown by frequently used ageing or elderly stallions can be put down to an „emotion-saving" reaction of the stallion to this phase of mating and gives no cause for complaint.

Maiden stallions, in particular, react sensitively to negative experiences in the manifestation of libido. The role of numerous libido suppressive measures in sport stallions should
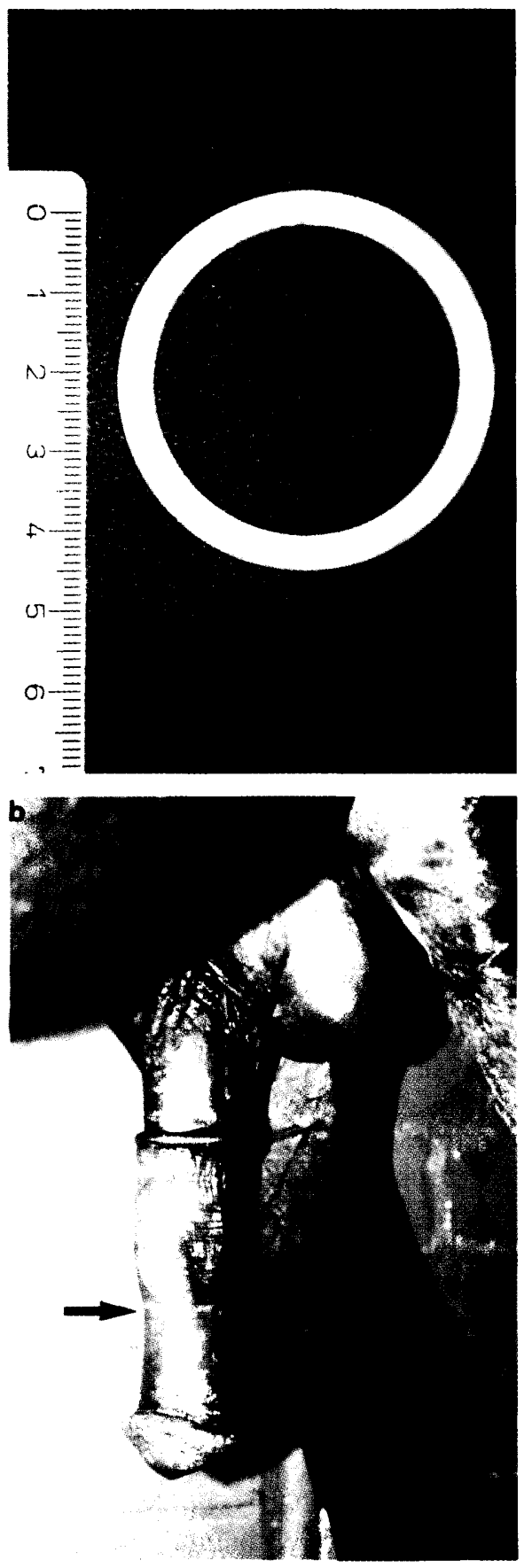

Fig. 1 a and b: Stallion ring (a) diameter $<40 \mathrm{~mm}$ for restricting acute sexual arousal; penile scars (b, arrow) from prolonged ring use

Penis ring (a) Durchmesser $<40 \mathrm{~mm}$ zur akuten Sexualtriebhemmung; Penishautnarben (b, Pfeil) durch langfristige Penisringstrangulation 
not be underestimated and are not directly detectable. The aim here, is not to discriminate against those actively involved in equine sport, but to point out that such measures are practised. Through personal observation recognition of the long-term or even permanent functional traumatization of the sexual drive and the chain of mating reflexes after the use of so-called penis rings in the training of race horses was possible. Stallions with such experiences seem to learn to suppress the reflectorial extension of the penis and therefore the erection which follows. Probands who have been malhandled are conspicuous through their significantly lengthened reaction time and the disturbance to the mating reflex chain as well as in the altered erectile process. Therapy relies solely on careful handling of the stallion including the organization of a natural copulation in species specific surroundings, bearing practicability of future matings in mind. Any recollection of past training practices should be avoided. Long-term application of a tight ring may cause reactions of the fore-skin and penis and any therapeutic attempts are generally unsuccessful. Here the erectile process remains disturbed (Fig. 1a and b).

Physical traumatization may also cause libido suppression, in particular in the young stallion in association with mating. This may be caused by a kick from the mare or through turbulent panic situations brought about through an unconventional manual mating method. Through careful continuation of the mating timetable it is possible to correct the results of trauma relatively quickly so that the libido suppression is only transient.

Despite the fact that no proof exists as to the negative effects of anabolic or androgenic substances, on the libido sexualis, they cannot be excluded (Berndtson et al., 1979; Squires et al. 1981 and 1982; Blanchard et al. 1983 and 1985). An indirect libido suppressive action, in the form of gonad degeneration, through high dose and long-term application of anabolic substances, is possible and must be taken into consideration whilst taking a history and during the examination.

Another form of libido disturbance is the so-called selective mating behaviour within the species. Here, stallions prefer or decline mares with a particular coat colour or with a particular reproductive status (foal mares, barren mares, foal season). The cause of this strange behaviour is unknown and it must simply be accepted.

With this background information any therapy of lack of libido must be directed at the individual causal components. Initially the individual nature and the particular history of a stallion patient must be identified. If the variations from the norm discovered are acceptable in the breeding regime of the owner, therapy is unnecessary. If this is not the case, the cause of the sexual inappetence must be recognized and if possible eliminated. Occasionally it may be necessary to experiment with, or vary the measures. Optimizing management and methods of handling, through the training of personnel, the frequency with which sexual performance is demanded as well as many other factors play an important role in assuring success in attaining a constant and prompt willingness to mate in the affected stallion. These changes in management can be supported through the application of pharmaca with a calming nature, such as diazepam or the use of antidepressive drugs such as the dibenzazepine imipramine (McDonnell, 1987).

Therapy through use of medication is very limited. The use of sexual steroids, in particular testosterone, in order to increase libido, is contraindicated. The positive effect of gonadotrophic substances, especially $\mathrm{GnRH}$, have been shown to generate the predictable and frequently described stimulatory effect on the sexual hormones which follow in the sequence. It does however not have any effect on the exocrine gonad function and the libido sexualis (Irvine et al. 1985 and 19991; Meinert, 1991; Blue et al.,1991; Boyle at al., 1991; Roser and Hughes 1991). Personal experiences, however, suggest that through application of a $\mathrm{GnRH}$ implant, once to three times, on a weekly basis, it is possible to achieve an increased libido. The extent to which endogenous substances, such as the endogenous opioids, which play a role in influencing the complex sexual processes, may be implemented therapeutically, currently lacks sufficiently detailed investigation.

\section{Erectile disorders}

The erection is the stiffening of the penis in the corresponding phase of the copulation, which occurs through the filling of the various erectile bodies with blood and is only then complete with the erectile development of the glans penis intra-vaginally. The mechanics associated with the development of the successive filling of the cavernous spaces under parasympathetic control, has been elucidated. The erection of the paired penis body corpus cavernosum penis (c.c.p), is achieved through the supply of arterial blood. Through a reduction in the swelling of the intima padding of the Ranken artery together with muscle relaxation of the trabecle and by-pass of a capillary bed the arterial blood flows directly into the cavities. Simultaneously arteriovenous shunts are closed so that a significant reservoir of blood is produced within the erectile body. The continuous availability of such a blood volume is made possible through a rhythmic pumping action of the M.ischiocavernosus. The erection of the glans erectile body and corpus spongiosum penis (c.s.p), occurs through a venous damming of blood flow and is maintained through a narrowing of the venous flow in the base of the penis.

The precision control of the erectile mechanism has been well documented, using man as the model (see fig. $2 a$ and b). This was of significant importance in the search for therapy of erectile dysfunction. The production of VIAGRA® has lead to success in this field (TruB et al., 1999). It is questionable as to whether the human model can be directly applied to horses. Personal experiments on a gelding, which had been conditioned using testosterone, showed that sildenofil, the active agent in viagra, was unable to prolong arterial and venous erection. Similar experiments on a sexually stimulated stallion gave a premature venous erection of the acorn and urethral erectile bodies, did not however cause prolonged erection of the corpus cavernosum penis (Klug and Bartmann, unpublished). 


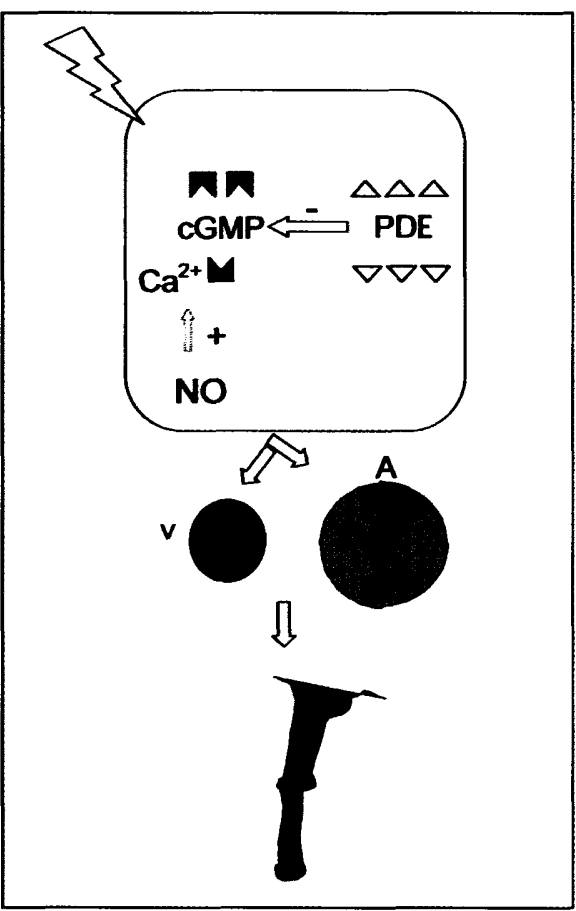

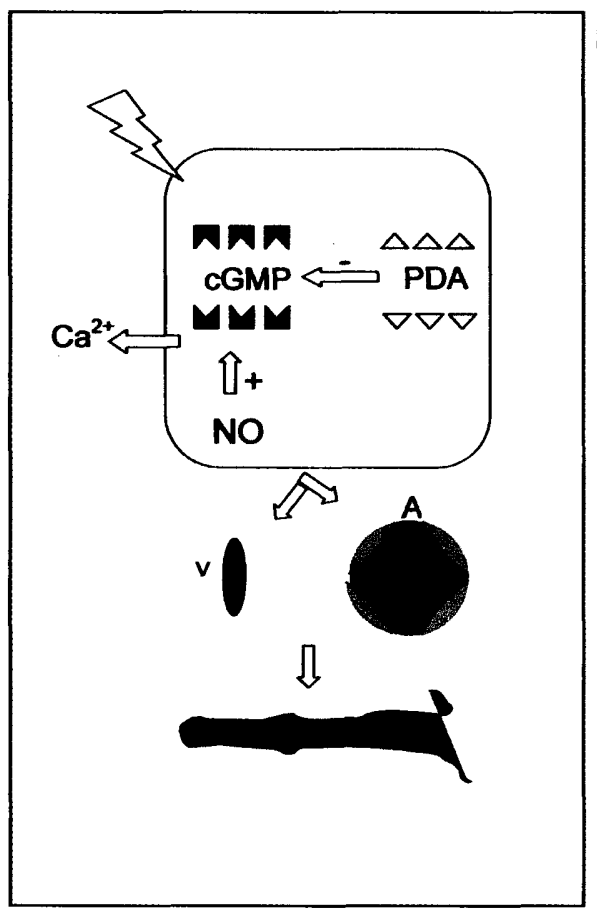

Fig. $2 \mathrm{a}$ and $\mathrm{b}$ :

Simplified model of musculo-cellular erectile mechanism; (a) intracellular phosphodiesterase (PDE) capacity higher than cyclic-guaninmonophosphate (cGMP) and low nitrogen oxide (NO) result in no or low calcium $(\mathrm{Ca} 2++)$ efflux and cavernomuscular cells remain contracted i.e. penis remains flaccid; (b) intracellular PDEconcentration lower than CGPM production and high NO concentration guarantee calcium efflux resulting in relaxation of cavernomuscular cells allowing intracavernal blood influx i.e. penis erects.

Vereinfachtes Modell zum muskulozellulären erektilen Mechanismus;

(a) intrazelluläre Phosphodiesterase(PDE)-kapazität, größer als zyklisches Guaninmonophosphatkonzentration (cGMP), und niedriger Stickoxyd (NO)gehalt resultieren in nur geringem oder keinem Calcium(Ca2+)efflux, sodass die kavernomuskulären Zellen kontrahiert sind und der Penis schlaff bleibt; (b) die intrazelluläre PDE-Kapazität, geringer als die cGMP-Konzentration und flankiert durch höhere NO-Konzentration, führt zum Calciumefflux und zur kavernomuskulären Relaxation und damit zur Blutfüllung der Schwellräume: der Penis versteift sich.

The causes and clinical manifestation of impotentia coeundi are manifold and are based on morphology and/or function. Table 2 is a summary of the most important variants of the disorder, along with frequency and therapeutic possibilities.

Penis hypoplasia in horses is very rare. The preputium has a normal structure (fig.3) so that, on extension, in order to urinate, the penis is "lost" within the foreskin layers and the proband becomes conspicuous through the characteristic "trouser pissing". Treatment for breeding purposes is out of the question. In order to ease urination the foreskin layers may however be split ventrally according to necessity.

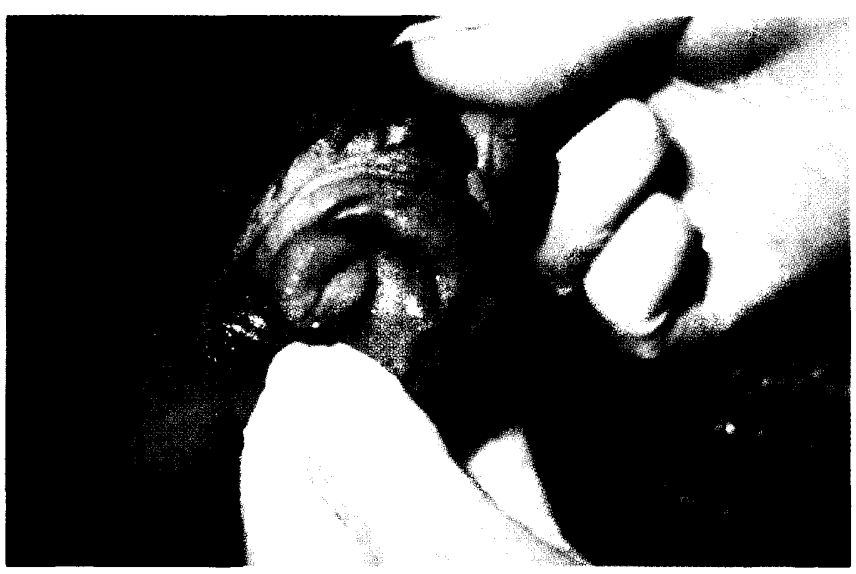

Fig. 3: penile hypoplasia

Penishypoplasie

Phimosis is defined as a prevention in extension of the penis due to a narrow fore-skin opening. In foals, 4-6 weeks of age this is at least partially physiological and is caused by an incomplete separation of the inner layers of the inter- nal fore-skin. Phimosis may be congenital (relatively rare) or more frequently acquired. Therapy is based on surgical correction, whereby breeding standards should be taken into consideration.

Paraphimosis is defined as an inability to retract the extended penis, altered through swelling, passed a fore-skin orifice which is absolutely or relatively too tight. Therapy initially includes conservative measures to reduce the swelling with compression etc. and is followed by attempts to replace the penis as well as to prevent reoccurrence through closure of the orifice using a purse-string suture (Frühauf et al., 1998).

Pseudoparaphimosis is an inability to extend the penis because of traumatic, inflammatory or neoplastic processes (see fig. 4a and b). Therapy is causal. Tumorous changes of the penis or fore-skin layers, which prevent extension and an initial erection may include fibropapilloma, squamous epithelium carcinoma, melanoma and less frequently the sarcoid. With the exception of the melanoma, therapy is based on surgical correction. Further deterioration in function cannot however be excluded.

Erectile disorders of a functional ethiopathological nature are relatively rare when considering the initial erection of the penis. More frequently an inability to produce a reservoir of blood within the corpus cavernosum penis, makes intromission impossible. Another variation of erectile disorder occurs with even greater frequency and is often confused with disturbances in ejaculation. In this case the proband develops normal erection of the penile erectile body, so that the penis easily penetrates and friction movements are carried out. The stallion however interrupts the mating process after only a few pelvic thrusts, during which the acorn is not conti- 
nuously stimulated. Because of this lack of stimulation and break-down in the sensory chain no ejaculation occurs. The problem here is primarily an erectile disorder (Gehlen et al,
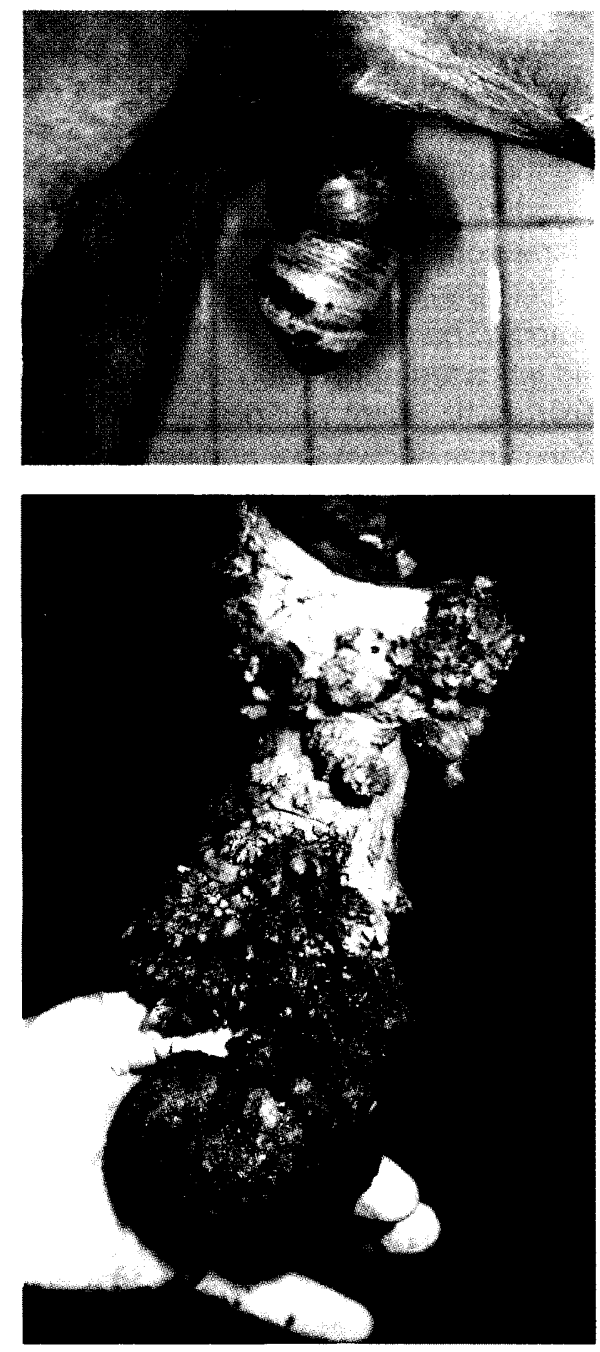

Fig. 4 a and b: pseudoparaphimosis caused by traumatic injury (a) and neoplasms (b)

Pseudoparaphimosis verursacht durch Trauma (a) und Neoplasie

1999), based on the absence of a venous reservoir in the spongial erectile bodies of the acorn and urethra. This is identified and called as erectile spongial dysfunction. Its cause is as yet unclear. As the disorder is rooted in the delicate mechanics and/or in the mechanical regulation of venous drainage, these must form the basis of therapeutic measures. Considering the regulatory processes on a musculocellular level, an increase in the concentration of cyclic guanosine monophosphate, made available through a blockage of phosphodiesterase and application of nitrogen oxide, leads to a better calcium efflux and therefore to arterial and, to a certain extent, venous narrowing. This must represent a therapeutic possibility. Specific investigations of this nature have not been carried out, in the stallion, they are however in the experimental stages. Personal investigations into the treatment of erectile spongial dysfunction through mechanical blocka- ge of the spongial system are shown in fig. 5a,b and c. Directly prior to penis intromission, of the mounted stallion, a simple, elastic rubber ring-cuff is placed around the penis
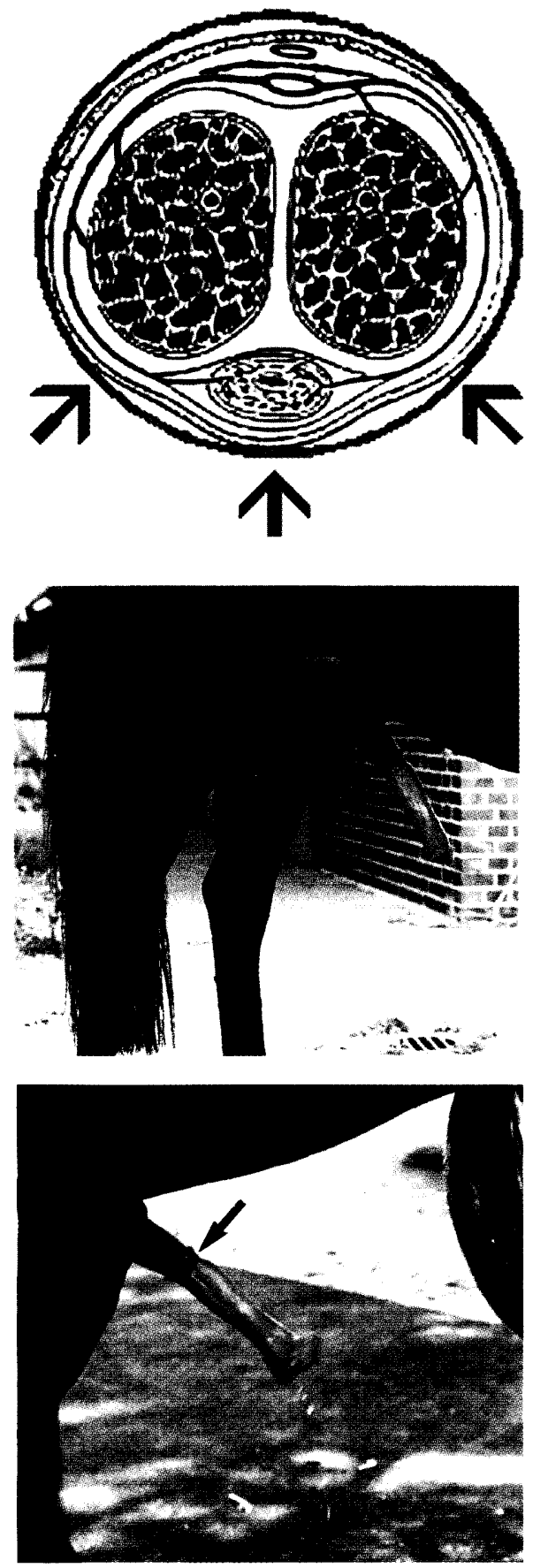

Fig. 5 a, b, and c: mechanic treatment of erectile spongial dysfunction (ESD); (a) penile cross section of anticipated site of rubber cuff, (b) rubber cuff on erected penis immediately before mounting, intromission and intra vaginal engorgement of glans penis, (c) pre intromission acorn engorgement (to be prevented)

Mechanische Behandlung der erektilen spongialen Dysfunktion (ESD); (a) schematischer Penisquerschnitt im Bereich des Manschettensitzes; (b) Manschette auf dem erigierten Penis unmittelbar vor Aufsprung, Intromission und Eichelanschwellung; (c) unerwünschte vorzeitige Eichelanschwellung durch die Manschettenwirkung 
penis shaft at the height of the external praeputial orifice. In this way a mechanical blockage of venous drainage within the corpus spongiosa penis and therefore, according to the natural sequence, of the acorn erectile body is achieved. In this way the sensitive stimulus appreciation of the acorn is reactivated and the break-down in the reflex chain is reconnected. In two breeding stallions treated using the relationship number of successful mountings (including ejaculation) to number of anamnetic and pretreatment unsuccessful mountings was increased from $0.5 / 10$ to $7 / 10$. It is important to note that the cuff is only applied directly before intromission as the swelling of the acorn which accompanies premature application hinders or prevents penis penetration.

Tab. 2: Erectile disorders in the stallion

Erektionsstörungen beim Hengst

\begin{tabular}{|c|c|c|}
\hline $\begin{array}{l}\text { Type of disorder } \\
\text { Art der Störung }\end{array}$ & $\begin{array}{l}\text { Incidence } \\
\text { Vorkommen }\end{array}$ & $\begin{array}{l}\text { therapeutic measures } \\
\text { therapeutische Maßnahmen }\end{array}$ \\
\hline $\begin{array}{l}\text { somatic ethiology } \\
\text { penis hypoplasia } \\
\text { phimosis } \\
\text { congenital } \\
\text { aquired } \\
\text { paraphimosis } \\
\text { pseudoparaphimosis } \\
\text { inflammatoric } \\
\text { neoplastic }\end{array}$ & $\begin{array}{ll}\text { rare } & \\
+ & \text { young } \\
+ & \text { young/old } \\
+ & \text { young/old } \\
& \\
+ & \text { young/old } \\
+ & \text { elder }\end{array}$ & $\begin{array}{l}\text { surgical } \\
\text { surgical } \\
\text { surgical } \\
\text { conservative } \\
\text { surgically }\end{array}$ \\
\hline $\begin{array}{l}\text { funct. ethiology } \\
\text { dysengorgement of } \\
\text { corp.cav. } \\
\text { corp.spong. } \\
\text { glandis } \\
\text { corp.spong. } \\
\text { penis } \\
\text { (erectile spon- } \\
\text { geous dysfunct.) } \\
\text { penis paralysis } \\
\\
\text { priapism }\end{array}$ & $\begin{array}{l}+ \text { young/old } \\
+\quad \text { young/ } \\
+\quad \text { old }\end{array}$ & $\begin{array}{l}\text { prophylaxis (EHV), conserv. } \\
\text { blockage of PDA (Phospho- } \\
\text { diesterase? } \\
\text { provision NO (Nitrogenoxids)? } \\
\text { blockage of venous drainage! } \\
\text { prophylaxis (EHV), void } \\
\text { phenothiacine derivates! } \\
\text { conserv. (suspensorium,etc.); } \\
\text { surgical? } \\
\text { emergency case! compres- } \\
\text { sion? suspensorium; } \\
\text { blockage of NO? } \\
\text { provision of PDA } \\
\text { surgical shunt operation } \\
\text { Ccp and Csp }\end{array}$ \\
\hline
\end{tabular}

Antidepressive drugs of the debenzepine group used to promote erection (McDonnell et al 1987) show a certain therapeutic success. The mode of action is probably not specifically aimed at the erectile process, but more at improving the entire sexual motivation and is therefore to a greater extent a libido promoting therapeutic.

Penis paralysis can occur through sedation with phenothiazine derivatives (Wheat, 1966; Nie and Pope, 1997;
Pearson and Weaver, 1978; Lucke and Sansam, 1979; Gerring, 1981) and also in connection with the hind limb ataxia associated with EHV infection or parasitic invasion (Oyamada et al., 1997). In both cases the muscular support and retraction apparatus is paralysed. Whilst it does not seem possible to treat the penis paralysis caused by ataxic malfunction of the hind limbs, the possibility exists that paralysis through medication may be reversible and can be supported through conservative therapy in the form of compression, suspension, reposition and closure of the praeputial opening. Treatment with medication has been attempted (Sharrock, 1982; Wilson et al., 1991) and in individual cases application of benzatropin mesylate, a cholinergolytic agent has proved successful. Personal experience has shown that application of romifidine (Sedivet $\AA$, Fa. Boehringer) causes an immediate and complete retraction of a penis paralysis induced by phenothiazine derivatives. Unfortunately this is only the case during the time that romifidine acts. The retraction is presumably due to the role romifidine plays in eliminating the sympatholysis brought about by the phenothiazine derivative.

A penis paralysis may result in a constant erection of the penis erectile body with or without the participation of the spongial blood cavities. This is known as priapismus and represents an emergency situation, because of the haemocoagulation which occurs in the blood cavities within a few hours, decreasing the chance of reversibility significantly. Conservative measures such as compression bandages and suspensory measures have no long-term success. Punction or centesis of the erectile cavities may be attempted as a surgical measure. Success has also been described in the surgical production of a so-called shunt between the cavernous and the spongial erectile system (Bolz, 1970; Schumacher and Hardin, 1987; Schumacher et al., 1999). The medicaments recommended in the literature, such as diuretics, are relatively ineffective. New therapeutic strategies using medication could make use of the cellular fine-regulation in the form of a reverse of that which was suggested for implementation in the case of erectile dysfunction. This would mean deprivation of nitrogen oxide and an increase in the availability of phosphodiesterase thereby leading to a decrease in guanosine monophosphate.

\section{Ejaculatory disorders}

The autonomous control of ejaculation occurs in two consecutive peristaltic waves. The first wave transports the cauda epididymal sperm suspension through the ductus deferens into the lumen of the pelvic portion of the urethra. From there the secrete is added to through the sequential emptying of the accessory secretions and is then propelled out by several numerous peristaltic waves via the urethra. The secrete portions are expelled in a specific sequence which allows fractionated sampling for diagnostic purposes. 
The transducturally transported secrete together with the excretions of the accessory glands are fittingly called the transduction (also known in the literature as emission). Both are almost entirely under sympathetic control. The transurethral ejection is controlled parasympathetically. Due to this segmental organization of the ejaculatory process, and the existence of various neuroreceptors, a basis for control of functional disorders is given, which may be influenced by exogenous therapeutic modulation (see table 3). The first investigative attempts to treat ejaculatory dysfunction were carried out and described by Vandeplassche (1955) and Rasbech (1975).

Tab. 3: Ejaculatory disorders

Ejakulationsstörungen

\begin{tabular}{|l|l|l|}
\hline $\begin{array}{l}\text { Type of disorder } \\
\text { Art der Störung } \\
\text { somatic ethiology } \\
\text { hypospadia }\end{array}$ & $\begin{array}{l}\text { incidence } \\
\text { Vorkommen }\end{array}$ & $\begin{array}{l}\text { therapeutic measures } \\
\text { Therapiemaßnahmen }\end{array}$ \\
\hline $\begin{array}{c}\text { functional ethiology } \\
\text { ejaculatio precox } \\
\text { ejaculatio retardata } \\
\text { ejaculatio retrograda }\end{array}$ & $\begin{array}{l}(+) \text { young/old } \\
(+)\end{array}$ & \\
urospermia & + young & $\alpha$ agonists, imipramin \\
ejacul. failure syndr. & + young/old & $\alpha$ agonists \\
occluded ampullae d.d. & + old & $\alpha$ agonists, $\beta$ blockade \\
\hline
\end{tabular}

Hypospadia refers to an inhibitory deformity of the penile urethra which is conspicuous in stallion foals. A surgical correction is possible (Bartmann und Klug 1997). It does however go without saying that these carriers are to be excluded from breeding.

Asynchronized ejaculation in the form of $E$. praecox have been described (McDonnell 1992; McDonnell et al. 1987) and have been observed by the author. Their incidence is however rare. A diagnosis is simple to make through close observation of the copulatory process. In contrast to man, where psychogenic influences are of primary importance, the cause in horses appears to be a neuro-motor dysregulation, which gives the reason for searching for new therapeutic measures in this area (Klug et al., 1978 and 1982; McDonnell et al., 1987). Ejaculatio retardata is clinically manifest through a delayed or partial transurethral ejection of the semen. This form of asynchronized ejaculation is also rare, but personal observations have been made and it has been described in the literature as an incomplete ejaculation (McDonnell, 1992). Causally, malhandling of the copulation, as well as neuromotory disorders, cannot be excluded, so that any therapeutics should begin with an investigation of the handling. Should this be unsuccessful, therapy attempts similar to those for other asynchronous disorders of ejaculation can be made.

Retrograde ejaculation of the stallion was described by Klug et al. (1978). If the definition of E.retrograda is to be strictly adhered to the patient described must be classed as a combination case with a urinary bladder paralysis following EHV infection and the resulting urospermia.

An example of habitual urospermia in the stallion may be seen after long periods of transport, during which the animals generally do not urinate. If these animals are used for semen collection, directly after being unloaded, contamination of the semen with urine is common. Permanent urospermia may be caused by a paralysis of the neck of the urinary bladder. Principally, causal therapy is based on the use of alpha-adrenergic substances (Klug et al. 1978). A precoital mechanical or medicamental emptying of the urinary bladder may however also be successful (Leenderste et al. 1990). The ejaculatory failure syndrome of the stallion has been described by Klug et al. (1982) and Klug et al. (1987). It is characterized by an anejaculation after a completely normal mating process until this point. The stallions mount-off following a period of species specific sexual behaviour and having shown regular friction movements, with a fully erect acorn erectile body, without having ejaculated. The complete erection of the corpus spongiosum glandis is the most important differential diagnostic characteristic in the exclusion of spongial erectile dysfunction. The ejaculatory failure syndrome appears to be caused by a neurogenic insufficiency of the autonomic, sympathetically controlled transduction. The aetiology orientated therapy is therefore based on an exogenous activation of specific receptors through the application of alphamimetic and beta blocking adrenergic substances (long-term clinical experience suggests a dosage of L-norephenephrine of $0.01 \mathrm{mg} / \mathrm{Kg} \mathrm{BW}$ i.m. 15 minutes before mating and carazolol $0.015 \mathrm{mg} / \mathrm{Kg}$ BW 10 minutes before covering). Other suggestions for therapy are based on the application of tricyclic antidepressive drugs such as imipramin as recommended by McDonnell (1987).

Ampullar sperm accumulation and stasis (Love, 1997; Mattos pers. communication) refers to the collection and a lack of transportation of sperm masses, which block the lumen and hinder further transduction or prevent it completely. The clinical picture is one of azoospermia and is seen exclusively in stallions, with a high sperm cell production capability, following a long period of sexual deprivation. Therapy relies on a transrectal manual massage of the ampullae, whereby the "sperm thrombus" is dislodged and possibly even dispersed.

Copulatory disorders through incoordination of the copulatory process must be investigated in the sexual apparatus as well as in the locomotory function of the patient. Genital causes are primarily based on an insensitivity of the glans penis or on directional changes of the penis following trauma, which can cause disturbances in intromission and are not treatable. Stallions with such disorders can however, as long as no other reflexes are disrupted, carry out a natural cover through manual correction or may of course be used in semen collection.

Hind limb ataxia, irrelevant of the cause, often causes inability to cover. Causal treatment is almost always difficult. Semen extraction with compensatory help may be possible in individual cases. 


\section{Literature}

Bartmann, C.P. and E. Klug (1997): Surgical diseases of the urogenital tract in the neonatal foal. Reprod. Dom. Anim 32, 67

Berndtson, W.E., B.W. Pickett and T.M. Nett (1974) Reproductive physiology of the stallion. IV. Seasonal changes in the testosterone concentration of peripheral plasma. J. Reprod. Fert. 39, 115-118

Berndtson, W.E., J.H. Hoyer, E.L. Squires and B.W. Pickett (1979): Influence of exogenous testosterone on sperm production, seminal quality and libido of stallions. J. Reprod. Fert. 27, 19-23

Blanchard, T.L. et al. (1983): The effects of stanozolol and boldenone undecycenate on scrotal width, testis weights, and sperm production in pony stallions. Theriogenology 20, 121-131

Blanchard, T.L. (1985): Some effects of anabolic steroids - especially on stallions. Compend Cont. Ed Pract. Vet. 7, 372-380

Blue, B.J., B.W. Pickett, E.L. Squires, A.O. McKinnon, T.M. Nett, R.P. Amann and K.A. Shiner (1991): Effect of pulsatile or continuous administration of $\mathrm{GnRH}$ on reproductive function of stallions. J. Reprod. Fert. 44, 145-154

Bolz, W. (1970): The Prophylaxis and Therapy of Prolapse and Paralysis of the Penis occurring in the Horse after the Administration of Neuroleptics. Vet. med. Rec., Leverkusen 4, 255-263

Boyle, M.S., J.Skidmore, J. Zhang and J.E. Cox (1991): The effects of continuous treatment of stallions with high levels of a potent $\mathrm{GnRH}$ analogue. J. Reprod. 44, 169-182

Frühauf, B., C.P. Bartmann, E. Klug (1998): Plastic surgery of covered and penetrating penis trauma in the stallion. European Society of Veterinary Orthopaedics and Traumatology (Hrsg.): 9th annual congress, Munich, 16-19.04.1998, 40

Gerring, E.L. (1981): Priapism and ACP in the horse. Vet. Rec. 109, 64

Gehlen, Heidrun, E. Klug and H. Bader (1999): Partielle Erektionsschwäche als Ursache einer Ejakulationsstörung bei einem Warmbluthengst - Einsatz der Elektroejakulation zur Abklärung der spermatogenen Hodenfunktion. Pferdeheilkunde 15, 341-344

Götze, R. (1942): Gewährleistung und Gewährfristen für die geschlechtliche Zuchttauglichkeit beim Kauf von Zuchthengsten. Dtsch. Tierärztl. Wochenschr. 50, 181-186

Gusmao, A.L. (1986): Sexualhormonprofile und Hormonstimulationen bei männlichen Pferden in unterschiedlichen Altersgruppen. Hannover, Tierärztl. Hochschule, Diss.

Irvine, C.H.G., and S.L. Alexander (1991): Effect of arousal on gonadotrophin-releasing hormone, luteinizing hormone and follicle-stimulating hormone secretion in the stallion. J. Reprod. Fert. 44, $135-143$

Irvine, C.H.G. et. al. (1985): Sexual behavior and serum concentration of reproductive homones in normal stallions. Theriogenology 23 , $607-617$

Klug, E., K.F. Weitze, K. Freytag, P. Witzmann, J. von Lepel and K.H. Neumann-Kleinpaul (1976): Zur Frage nach dem Begattungs- und Befruchtungsvermögen von Wallachen nach der Kastration. Dtsch. Tierärztl. Wochenschr. 83, 367-373

Klug, E., H. Merkt, J.D. von Lepel and K. Blobel (1978): Urospermie bei einem Hengst mit Hinterhandparese - Tiefgefrierkonservierung von befruchtungsfähigem Samen. Tierärztl. Umschau 33, 324-327

Klug, E., E. Deegen, B. Lazarz, I. Rojem, M. Merkt (1982): Effect of adrenergic neurotransmitters upon the ejaculatory process in the stallion. J. Reprod. Fert. 32, 31-34

Klug, E. (1987): Ejaculatory failure. in: N.E. Robinson (ed) Current Therapy in Equine Medicine. Philadelphia

Leendertse, J.P., A.C. Asbury, K.J. Boening and F.C. von Saldern (1990): Sucessful management of persistent urination during ejaculation in a Thoroughbred Stallion. Equine Vet. Educ. 2,62-64

Love, C.C. (1997): Reproductive Diseases in the Stallion. in: Robinson, N.E. (ed) Current Therapy in Equine Therapy. Saunders, Phialelphia

Lucke, J.N. and Samson, J. (1979): Penile Erection in the Horse after Acepromacine. Vet. Rec. 105, 21-22
McDonell, S.M. (1992): Normal and Abnormal Sexual Behavior. Vet. Cl. North. Am. Equine Practice 8, 71-88

McDonell, S.M. et al. (1987): Pharmacological manipulation of sexual behavior in stallions. J. Reprod. Fert. 35, 45-49

Meinert, C. (1991): Untersuchungen zur Beeinflussung des Ovulationszeitpunktes bei der Stute durch Applikation von HCG- oder Gn$\mathrm{RH}$-Implantat anhand klinischer, sonographischer und hormoneller Parameter. Hannover, Tierärztl. Hochschule, Diss.

Merkt, H. and E. Klug (1989): Gesundheitliche und geschlechtliche Mindestanforderungen an Zuchthengste. Dtsch. Tierärztl. Wochenschr. 96, 459-464

Nie, G.J. and K.C. Pope (1997): Persistent penile prolapse associated with acute blood loss and acepromazine maleate administration in a horse. J. Am. Vet. Med. Assoc. 211, 587-589

Oyamada, T., K. Miyaijma, Y. Kimuara, M. Kikuchi, S. Nakanishi and H. Yoshikawa (1997): Priapism Possibly Caused by Spinal Nematodiasis in a Stallion. J. Equine Sci. 8, 101-107

Pearson, H. and B.M.Q Weaver (1978): Priapism after Sedation, Neuroleptanalgesia and Anaesthesia in the Horse. Equine vet. J. 10, 85-90

Pickett, B.W.,L.C. Faulkner. and T.M. Sutherland (1970): Effect of month and stallion on seminal characteristics and sexual behavior. J. Anim. Sci. 31, 713-728

Pickett, B.W., , R.P. Amann, A.O. McKinnan, E.L. Squires and J.L. Voss (1989): Management of the stallion for maximum reproductive efficiency. II. Animal Reproduction Laboratory Bulletin on Fort Collins USA

Roser, J.F. and J.P. Huges (1991): Prolonged pulsatile administration of gonadotrophin-releasing hormone $(\mathrm{GnRH})$ to fertile stallions. J. Repro. Fert. 44, 155-168

Schumacher, J., D.K. Hardin (1987): Surgical treatment of priapism in a stallion. Vet. Surg. 16, 193-196

Schumacher, J., D.D. Varner, M.R. Crabill, T.L. Blanchard (1999): The Effect of a Surgically Created Shunt Between the Corpus Cavernosum Penis and Corpus Spongiosum Penis of Stallions on Erectile and Ejaculatory Function. Vet. Surg. 28, 21-24

Sharrock, A.G. (1982): Reversal of drug - induced priapism in a gelding by medication. Aust. Vet. J. 58, 39

Squires, E.L. et al. (1982): Effect of anabolic steroids on reproductive function of young stallions. J. Anim. Sci. 54, 576-582

Squires, E.L., W.E. Berndtson, J.H. Hoyer, B.W. Pickett and S.J.R. Wallach (1981): Restoration of reproductive capacity of stallions after suppression with exogenous testosterone. J. Anim. Sci. 53, 1351-1359

Vandeplassche, M. (1955): Ejakulationsstörungen beim Hengst. Dtsch. Tierärztl. Wochenschr. 5, 134-137

Rasbeck, N.O. (1975): Ejaculatory disorders of the stallion. J. Reprod. Fertil. 23, 123-128

TruB, M. C., A. J. Becker, D. Schultheiss, S. Machtens, U. Jonas, C. G. Stief (1999) Medikamentöse Therapie der erektilen Dysfunktion. Reproduktionsmedizin, 15, 212-219

Wheat, J.D. (1966): Penile paralysis - stallions given propiopromazine. J. Am. Vet. Vet. Med. Assoc. 148, 405-406

Wilson, D.V., F.A. Nickels and M.A. Williams (1991): Pharmacologic treatment of priapism in two horses. J. Am. Vet. Med. Assoc. 119, 1183-1184

Prof. Dr. E. Klug

Dr. C. P. Bartmann

Dr. Heidrun Gehlen

Klinik für Pferde

Tierärtliche Hochschule Hannover

Bischofsholer Damm 15

30173 Hannover

Tel./Fax: 0511 - 856 7589/7681

Email: erklug@pfdkli.tiho-hannover.de 